\title{
NOTE
}

\section{Polymerase chain reaction (PCR) detection of white spot syndrome virus (WSSV) in cultured and wild crustaceans in India}

\author{
S. K. Otta, G. Shubha, B. Joseph, Anirban Chakraborty, Indrani Karunasagar, \\ Iddya Karunasagar*
}

Department of Fishery Microbiology, University of Agricultural Sciences, College of Fisheries, Mangalore 575002, India

\begin{abstract}
A study was carried out to evaluate polymerase chain reaction (PCR) for the detection of white spot syndrome virus (WSSV) in postlarvae and broodstock of Penaeus monodon and in potential crustacean carriers from India. Primer pairs designed for WSSV affecting Penaeus japonicus (WSSV $\mathrm{PJ}$ ) and P. monodon (WSSV PM) were used. Both the primer pairs gave positive assay results for crustaceans showing gross signs of WSSV infection. However, all grossly healthy postlarvae and broodstock gave negative results with both the WSSV PJ and WSSV PM primer pairs by non-nested PCR. Some of the grossly normal specimens were positive for WSSV by nested PCR using WSSV PM primers. So also was water from shrimp culture ponds experiencing WSSV outbreaks. In addition, 1 sample of Artemia nauplii was positive for WSSV PM by nested PCR. Among crab samples examined, a few samples of Scylla serrata and Sesarma oceanica from around the pond area and marine crabs such as Matuta planipes and Charybdis lucifera from trawl catches were positive for WSSV, indicating that wild marine crabs could be reservoirs of WSSV infection. The results indicated that WSSV carriers are common in natural shrimp stocks and other crustaceans in India.
\end{abstract}

KEY WORDS: White spot syndrome - Virus - Polymerase chain reaction - Cultured shrimp. Wild crustaceans

White spot syndrome virus (WSSV) has caused serious epizootics in cultured shrimp in several parts of south and southeast Asia (Takahashi et al. 1994, Chen 1995, Chou et al. 1995, Wang et al. 1995, Wongteerasupaya et al. 1995, Karunasagar et al. 1997). This virus is known to effect most commercially important species of penaeid shrimp including Penaeus monodon, $P$. japonicus, $P$. indicus, $P$. chinensis, $P$. merguensis, $P$. aztecus, $P$. stylirostris, $P$. vannami, $P$. duorarum and $P$. setiferus (Lightner 1996). WSSV infection is characterised by the gross signs of rapid reduction in food consumption and a loose cuticle with white spots on

\footnotetext{
- Addressee for correspondence.

E-mail: mircen@giasbg01.vsnl.net.in
}

the inner surface (Takahashi et al. 1994). In some cases, moribund shrimp may also display reddish brown colouration (Nakano et al. 1994). In outbreak shrimp ponds, cumulative mortality may reach 80 to $100 \%$ within 7 to $10 \mathrm{~d}$ post-infection (Nakano et al. 1994, Karunasagar et al. 1997)

Diagnosis of WSSV infections can be confirmed in stained squashes or impression smears of sub-cuticular epithelial tissue, connective tissue and gills by observation of hypertrophied nuclei containing marginated chromatin and amphophilic central inclusions (Chou et al. 1995, Lightner 1996). Molecular methods such as gene probes (Durand et al. 1996, Lo et al. 1996a, Wongteerasupaya et al. 1996, Nunan \& Lightner 1997) and polymerase chain reaction (Takahashi et al. 1996, Lo et al. 1996b) have also been found useful in diagnosing WSSV infection, particularly with carrier animals showing no gross signs of disease. Thus, these molecular methods are helpful in screening for the presence of WSSV in potential carriers and in post larvae (PL) before they are stocked into rearing ponds. Lo et al. (1996a) noted that the sensitivity of their PCR assay could be increased $10^{3}$ to $10^{4}$ times by using a second amplification step employing nested primers.

This study evaluated 2 published PCR methods, both non-nested and nested, for detection of WSSV in WSSV-infected and grossly normal larvae and potential carrier animals in India. The objective was to determine whether WSSV was present in wild, natural stocks.

Materials and methods. Collection of samples: PL of Penaeus monodon (PL 8 to PL 20) were sampled randomly from local hatcheries along the west coast of India. They were kept in oxygen-packed polythene bags for transport to the laboratory. From the same hatcheries, broodstock specimens were also collected both before and after eyestalk ablation. Other brood- 
stock specimens were captured directly from the sea off Goa and transported immediately to the laboratory for analysis. In addition, juvenile and adolescent shrimp were collected from culture ponds and transported to the laboratory packed in polythene bags. Natural juvenile shrimp were also captured from shrimp farm waterways and from nearby estuaries and transported to the laboratory in the same way. Several crab species from around the pond area were collected and samples of marine crabs were collected from trawl catches at the fish landing centre. The details of species examined are given in Table 1 . Water from various culture ponds and pond water sources was sampled in sterile bottles and brought to the laboratory for analysis.

Extraction of DNA: For extraction of DNA, samples were processed as follows. About 20 to 30 PL or numerous Artemia nauplii (total volume approximately $100 \mu \mathrm{l}$ ) were collected in a sterile $1.5 \mathrm{ml}$ microfuge tube and macerated into fine particles using a glass rod. In the case of juvenile, adolescent and broodstock shrimp and crabs, samples of gill, cuticular, stomach or muscle tissue were collected (approximately $400 \mathrm{mg}$ ) and macerated into fine particles in microfuge tubes. Water samples were taken in $50 \mathrm{ml}$ centrifuge tubes and centrifuged at $17000 \times g$ for $45 \mathrm{~min}$ at $4^{\circ} \mathrm{C}$. The supernatant was removed and fresh sample was added followed by further centrifugation until $300 \mathrm{ml}$ of each water sample had been processed. The final pellet was collected and transferred to a microfuge tube.
After sample processing, 400 pl of lysis buffer (100 $\mathrm{mM} \mathrm{NaCl}, 10 \mathrm{mM}$ Tris $\mathrm{HCl}$ pH 8.0, $25 \mathrm{mM}$ EDTA $\mathrm{pH} 8,0.5 \%$ SDS, $0.1 \mathrm{mg} \mathrm{ml}^{-1}$ of proteinase $\mathrm{K}$ ) was added to each microfuge tube and they were incubated at $56^{\circ} \mathrm{C}$ for 8 to $10 \mathrm{~h}$ in a water bath. The samples were subsequently re-homogenized before centrifugation at $800 \times g$ for $5 \mathrm{~min}$ to remove any debris. The supernatant was then collected and DNA was extracted by the standard phenol-chloroform method. In the final step, DNA was precipitated by addition of $1 / 10$ volume of $3 \mathrm{M}$ sodium acetate and 3 volumes of absolute ethanol and storage overnight at $-20^{\circ} \mathrm{C}$. The DNA sample tubes where then centrifuged at $17000 \times$ $g$ for $30 \mathrm{~min}$ at $4^{\circ} \mathrm{C}$ before the supernatant was removed and the remaining alcohol evaporated for storage. Before use, the DNA pellet was dissolved with $50 \mathrm{\mu l}$ of TE buffer $(10 \mathrm{mM}$ Tris $\mathrm{HCl} \mathrm{pH} 8,1 \mathrm{mM}$ EDTA $\mathrm{pH} 8$ ).

Amplification of WSSV DNA: Primers named PJ1 and PJ2 were those described by Takahashi et al. (1996). Primer pairs named PMI/PM2 and PM3/PM4 were those described by Lo et al. (1996b) as 146 F1/146 R1 (outer) and 146 F2/146 R2 (inner) pairs, respectively, for nested PCR. PCR reactions were carried out in $50 \mu \mathrm{l}$ of reaction mixture that consisted of $5 \mu \mathrm{l}$ of $10 \mathrm{x}$ reaction buffer (20 mM Tris- $\mathrm{HCl} \mathrm{pH} 7.5,10 \mathrm{mM} \mathrm{MgCl}_{2}$, $1 \mathrm{mM} \mathrm{DTT}, 50 \mu \mathrm{g} \mathrm{ml}^{-1}$ nuclease free BSA $), 1 \mu \mathrm{l}(0.5 \mu \mathrm{g})$ of each primer, $200 \mu \mathrm{M}$ of each dNTPs, $1 \mu$ l of template DNA and 2.25 units of Taq DNA polymerase made up to volume with sterile distilled water. PCR was per-

Table 1. Detection of white spot syndrome virus (WSSV) in various samples using non-nested and nested PCR. PL = post larvae

\begin{tabular}{|c|c|c|c|c|c|c|}
\hline $\begin{array}{l}\text { Sample } \\
\text { no. }\end{array}$ & Type & $\begin{array}{l}\text { Gross } \\
\text { signs }\end{array}$ & $\begin{array}{l}\text { No. } \\
\text { examined }\end{array}$ & $\begin{array}{l}\text { Non-nested } \\
\text { PM1/PM2 }\end{array}$ & $\begin{array}{l}\text { CR positive } \\
\text { PM3/PM4 }\end{array}$ & $\begin{array}{c}\text { Nested PCR } \\
\text { positive }\end{array}$ \\
\hline 1 & PL & Healthy & 58 & 0 & 3 & 28 \\
\hline 2 & Juvenile shrimp & Healthy & 3 & 0 & 0 & 3 \\
\hline 3 & Juvenile shrimp & White spots & 1 & 0 & 1 & 1 \\
\hline 4 & Adolescent shrimp & Healthy & 2 & 0 & 0 & 0 \\
\hline 5 & Wild shrimp & Healthy & 1 & 0 & 0 & 1 \\
\hline 6 & Artemia & Healthy & 1 & 0 & 0 & 1 \\
\hline 7 & Brooder shrimp & Healthy & 3 & 0 & 0 & 3 \\
\hline 8 & Brooder shrimp & White spots & 7 & 7 & 7 & 7 \\
\hline 9 & Water & - & 8 & 0 & 4 & 6 \\
\hline \multirow[t]{11}{*}{10} & Crabs & & & & & \\
\hline & Scylla serrata & White spots & 1 & 0 & 1 & 1 \\
\hline & Scylla serrata & Healthy & 20 & 0 & 0 & 3 \\
\hline & Sesarma oceanica & Healthy & 10 & 0 & 0 & 1 \\
\hline & Charybdis cruciatad & Healthy & 10 & 0 & 0 & 0 \\
\hline & C. Iucifera & Healthy & 5 & 2 & 2 & 2 \\
\hline & Portunus sanguinolentus ${ }^{d}$ & Healthy & 2 & 0 & 0 & 0 \\
\hline & Doclea gracilipes & Healthy & 1 & 0 & 0 & 0 \\
\hline & Macropthalmus sulcatus ${ }^{d}$ & Healthy & 1 & 0 & 0 & 0 \\
\hline & Pseudograpsus intermedius & Healthy & 19 & 0 & 0 & 0 \\
\hline & Matuta planipes & Healthy & 2 & 2 & 2 & 2 \\
\hline
\end{tabular}


formed in a thermocycler (TECHNE, Genius, Germany) for 30 cycles with the following protocol: denaturation at $94^{\circ} \mathrm{C}$ for $1 \mathrm{~min}$, annealing at $54^{\circ} \mathrm{C}$ for $1 \mathrm{~min}$ and extension at $72^{\circ} \mathrm{C}$ for 2 min except for the first and last steps which were prolonged for $5 \mathrm{~min}$. For nested (2-step) PCR (Lo et al. 1996b), $1 \mu$ l of a post-PCR mixture using the primer pair PM1/PM2 was used as the template for a second $\mathrm{PCR}$ reaction (same conditions as above) with the primer pair PM3/PM4. PCR reaction products were separated on $1 \%$ agarose gel that incorportated ethidium bromide for band visualization using a UV transilluminator.

Results and discussion. In initial PCR assays, the primer pairs PJ1/PJ2 designed by Takahashi et al. (1996) and PM1/PM2 designed by Lo et al. (1996b) gave WSSV positive reactions for samples of Penaeus monodon juveniles showing symptoms of WSSV infection (Table 2). These samples also gave WSSV positive results in non-nested PCR reactions using the primer pair PM3/PM4, usually used only as a nested primer pair. However, by non-nested PCR with these primer pairs, none of the 23 samples of grossly healthy $\mathrm{PL}$ gave WSSV positive reactions. On the other hand, 14 of the $23(61 \%)$ gave WSSV positive reactions by nested (2-step) PCR (Table 2). Based on these results, further tests were carried out using only the PM primer pairs.

In subsequent tests, only 3 samples $(5 \%)$ of grossly healthy PL batches $(n=58)$ gave WSSV positive PCR assays for WSSV by non-nested PCR, while $28(48 \%)$ gave WSSV positive reactions by nested PCR. Curiously, the 3 WSSV positive reactions were obtained using primer pair PM3/PM4, while primer pair PM1/PM2 gave a negative reaction with the same samples. For shrimp and crabs showing gross signs of WSSV infection, WSSV positive PCR reactions were obtained by non-nested PCR, but again, only with primer pair PM3/PM4 and not with PM1/PM2. Perhaps this was because of the smaller amplicon size from PM3/PM4 (941 bp), when compared to that of PM1/ PM2 (1447 bp). The results showed that a significant proportion of grossly healthy Penaeus monodon postlarvae from Indian hatcheries may carry WSSV. Thus, there is a need to screen apparently healthy PL for WSSV by PCR before stocking in ponds. In addition, our results confirm the observation of Lo et al. (1996a) that the high sensitivity of a nested PCR reaction may be necessary to identify infected PL batches.

Of the 10 samples of broodstock examined, 3 were apparently healthy while 7 showed gross signs of WSSV infection. The 3 grossly healthy specimens gave WSSV positive, nested PCR results while the other 7 specimens with gross signs of WSSV were WSSV positive in assays using non-nested PCR with both primer pairs. These results indicate that wild broodstock obtained from natural Indian waters may be infected with WSSV and bring it into the hatchery. However, no estimate can be made of the prevalence in the wild because of the small sample size and the fact that the specimens were obtained from hatcheries where prevalence may have increased by horizontal transfer after capture. From both Taiwan (Lo et al. 1996a) and Japan (Itami et al. 1998), where wild shrimp broodstock have been reported to carry WSSV, they have been implicated as a source of WSSV infection for PL. Given the high number of WSSV infected brooders (10/10 tested) found in this study, it is not surprising that so many PL batches also tested WSSV positive, and it is probable, as in Taiwan and Japan, that a major route of potential viral entry into the Indian cultivation system is PL infected via captured broodstock.

After the WSSV outbreaks in India during late 1994, farmers observed several instances of white spots occurring in the cuticle of the mud crab Scylla serrata. This crab species has been shown to be a WSSV carrier in Taiwan (Lo et al. 1996a) and Thailand (Kanchanaphum et al. 1998, Supamattaya et al. 1998). We tested by PCR one specimen with white spots in the cuticle and 20 healthy samples from around a pond area. The specimen with white spots was positive by both nonnested (primers PM3/PM4) and nested PCR. Among 20 healthy samples, 3 were positive by nested PCR. These results indicate that $S$. serrata in India is also a WSSV host. In addition to $S$. serrata, a number of other crab species were tested as indicated in Table 1 Some of them were marine crabs from trawl catches, while others were caught from shrimp ponds. Interestingly, 2 samples of Matuta planipes from trawl catches were WSSV positive by non-nested PCR, indicating that this crab species is a host. Of 5 samples of Charybdis lucifera from trawl catches, 2 were WSSV positive by non-nested PCR. One sample of Sesarma oceanica

Table 2. Results of non-nested and nested PCR assays using primers described for WSSV in Penaeus japonicus (PJ) and P. monodon (PM)

\begin{tabular}{|lllcccc|}
\hline $\begin{array}{l}\text { Sample } \\
\text { no. }\end{array}$ & $\begin{array}{l}\text { Shrimp } \\
\text { stage }\end{array}$ & $\begin{array}{l}\text { Gross } \\
\text { signs }\end{array}$ & No. & \multicolumn{2}{c|}{$\begin{array}{c}\text { Non-nested PCR positive } \\
\text { PJ primers }\end{array}$} & $\begin{array}{c}\text { Nested PCR primers } \\
\text { positive }\end{array}$ \\
\hline 1 & PL & Healthy & 23 & 0 & 0 & 14 \\
2 & Juvenile & White spots & 3 & 3 & 3 & 3 \\
\hline
\end{tabular}


from shrimp pond areas was WSSV positive by nested PCR. Our results document that marine crabs can host WSSV and act as reservoirs for shrimp infection.

Of 8 samples of pondwater examined for the presence of WSSV, 4 were WSSV positive by non-nested PCR (primers PM3/PM4) and 6 by nested PCR. Only 2 were negative. These results indicate a high viral load in pond water. Since DNA was extracted from pellets after centrifugation at only $17000 \times g$, the pellets would have contained plankton and other particulate components, but few, if any, free virus particles from the water. Thus, the WSSV positive PCR reaction with the pellets must have arisen from WSSV carriers or from viral particles attached to particulate matter.

Although taken from a tank where the PL sampled gave a WSSV negative PCR reaction, 1 sample of Artemia gave a WSSV positive PCR reaction by nested PCR. It is not known whether the Artemia was infected with WSSV or simply contaminated with it during hatching and handling (e.g. via the water). However, the results indicate that Artemia feeding may potentially expose PL to WSSV.

Acknowledgements. The authors are grateful to the Department of Biotechnology, Govt. of India for supporting grants and the Alexander Von Humboldt Foundation, Germany, for the generous donation of a thermocycler.

\section{LITERATURE CITED}

Chen SN (1995) Current status of shrimp aquaculture in Taiwan. In: Swimming through troubled water. Proc Special Session on Shrimp Farming. Aquaculture 1995. World Aquaculture Society, Baton Rouge, LA, p 29-34

Chou HY, Huang CY, Wang $\mathrm{CH}_{1}$ Chiang HC, Lo CF (1995) Pathogenicity of a baculovirus infection causing white spot syndrome in cultured penaeid shrimp in Taiwan. Dis Aquat Org 23:165-173

Durand S, Lightner DV, Nunan LM, Redman RM, Mari J, Bonami JR (1996) Application of gene probes as diagnostic tools for the White Spot Baculovirus (WSBV) of penaeid shrimps. Dis Aquat Org $27: 59-66$

Itami T, Maeda M. Suzuki N, Tikushige $K$, Nakagawa $A$, Hennig $O$, Kondo M, Kasornchandra J, Hirono I, Aoki T, Kusuda R, Takahashi $Y$ (1998) Possible prevention of white spot syndrome (WSS) in Kuruma shrimp, Penaeus japonicus, in Japan. In: Flegel TW (ed) Advances in shrimp biotechnology. National Center for Genetic Engineering and Biotechnology, Bangkok, p 291-295

Kanchanaphum $P$, Wongteerasupaya $C$, Sitidilokratana N, Boonsaeng $V$, Panyim S, Tassanakajon A, Withyachumnarnkul B, Flegel TW (1998) Experimental transmission of White Spot Syndrome virus (WSSV) from crabs to shrimp Penaeus monodon. Dis Aquat Org 34:1-7

Editorial responsibility: Timothy Flegel,

Bangkok, Thailand
Karunasagar I, Otta SK, Karunasagar I (1997) Histopathological and bacteriological study of white spot syndrome in Penaeus monodon along the west coast of India. Aquaculture 153:9-13

Lightner DV (1996) A handbook of pathology and diagnostic procedures for diseases of penaeid shrimp. Section 3.11. World Aquaculture Society, Baton Rouge, LA

Lo CF, Ho CH, Peng SE, Chen CH, Hsu HC, Chiu YL, Chang CF, Liu KF, Su MS, Wang CH, Kou GH (1996a) White spot syndrome baculovirus (WSBV) detected in cultured and captured shrimp, crabs and other arthropods. Dis Aquat Org 27:215-225

Lo CF, Leu JH, Ho CH, Chen CH, Peng SE, Chen YT, Chou

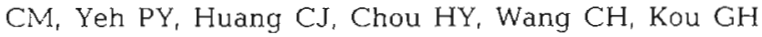
(1996b) Detection of baculovirus associated with white spot syndrome (WSBV) in penaeid shrimps using polymerase chain reaction. Dis Aquat Org 25:133-141

Nakano H, Koube H, Umezawa S, Momoyama K, Hiraoka M, Inouye K, Oseko N (1994) Mass mortality of cultured Kuruma shrimp, Penaeus japonicus, in Japan in 1993: epizootiological survey and infection trials. Fish Pathol 29: $135-139$

Nunan LM, Lightner DV (1997) Development of a nonradioactive gene probe by PCR for detection of white spot syndrome virus (WSSV). J Virol Methods 63:193-201

Supamattaya K, Hoffmann RW, Boonyaratpalin S, Kanchanaphum P (1998) Experimental transmission of white spot syndrome virus (WSSV) from black tiger shrimp Penaeus monodon to the sand crab Portunus pelagicus, mud crab Scylla serrata and krill Acetes sp. Dis Aquat Org 32:79-85

Takahashi $Y$, Itami T, Kondo M, Maeda M, Fujii R, Tomonaga S, Supamattaya K, Boonyaratpalin S (1994) Electron microscopy evidence of bacilliform virus infection in Kuruma shrimp (Penaeus japonicus). Fish Pathol 29: $121-125$

Takahashi Y, Itami T, Maeda M, Suzuki N, Kasornchandra J, Supamattaya K, Khongpradit R, Boonyaratpalin S, Kondo M, Kawai K, Kusuda R, Hirono I, Aoki T (1996) Polymerase chain reaction (PCR) amplification of bacilliform virus (RV PJ) DNA in Penaeus japonicus Bate and systemic ectodermal and mesodermal baculovirus (SEMBV) DNA in Penaeus monodon Fabricus. J Fish Dis 19:399-403

Wang CH, Lo CF, Leu JH, Chou CM, Yeh PY, Chou HY, Tung MC. Chang CF, Su MS, Kou GH (1995) Purification and genomic analysis of baculovirus associated with white spot syndrome (WSBV) of Penaeus monodon. Dis Aquat Org 23:239-242

Wongteerasupaya C, Vickers JE, Sriurairatana S, Nash GL, Akarajamorn A, Boonsaeng $V$, Panyim S, Tassanakajon A, Withyachumnarnkul B, Flegel TW (1995) A nonoccluded systemic baculovirus that occurs in cells of ectodermal and mesodermal origin and causes high mortality in the black tiger prawn Penaeus monodon. Dis Aquat Org 21:69-77

Wongteerasupaya C, Wongwisansri, Boonsaeng V, Panyim S, Pratanpipat P. Nash GL, Withyachumnarnkul B, Flegel TW (1996) DNA fragment of Penaeus monodon baculovirus Pm NOBII gives positive in situ hybridisation with whute spot viral infections in six penaeid shrimp species. Aquaculture 143:23-32

Submitted: October 16, 1998; Accepted: July 14, 1999 Proofs received from author(s): August 27, 1999 